\title{
Nigerian Federalism And The Statutory Allocation Of Funds: Analytical Review Of Local Government As Third Tier Of Government
}

\author{
Abdulrashid Lawan Haruna, Goni Usman Al-Ansar \\ Ph.D. Candidate, International Islamic University Malaysia,A Lecturer, Faculty of Law, University of \\ Maiduguri, Nigeria \\ Ph.D. Candidate, University of Maiduguri, A Lecturer, Faculty of Law, University of Maiduguri, Nigeria
}

\begin{abstract}
Federalism has been a mechanism that upholds unity in diversity and recognizes the value and significance of respect for minority's aspirations through vertical power sharing in a state within the federation. In Nigeria, local government system existed under different forms of system even prior to Nigerian independence but it was the Local Government reform of 1976 that institutionalized the system and made it the third tier of government. The function of local government as the third tier is in its capability of meeting the political needs of the people at the grass root as well as rendering economic and social services. Notwithstanding, the Constitutional guarantee of democratically elected local government councils, there seems to be erosion of the ideals and values that necessitate the establishment of the third tier. In light of this, the paper examines the Constitutional provision relating to Local Government statutory allocation with a view to ascertaining whether state governments should retain control of Local Government finances or not, and whether the deduction from the coffers of local governments by the state governments is lawful and justifiable.
\end{abstract}

Key Words: Constitution, Elected Councils, Federalism, Local Government, Statutory Allocation

\section{Introduction}

It is indeed necessary that Nigeria adopted a system of government where powers of state are divided and shared vertically among the three tiers of government-federal, state and local governments. The decentralization of governmental functions in a federal system gave the opportunity to local government as a tier to have direct bearing on the common man in the society so as to render socio-economic services to him. All local affairs of the community are within the powers and functions of local government in such a way that local needs of the people are catered for by the immediate local authority within limited possible resources allocated to it or internally generated. In Nigeria, the composition of local government councils is made up of democratically elected representatives of the people and the councils survive largely on statutory allocations from the federal and state governments. In recent time, state governments often temper with the democratically constituted councils, and also temper with the statutory allocation of the local governments that is paid into the State Joint Local Government Account meant for distribution to respective local government councils in the state.

It is against this background that the paper looks at general concept of federalism and its practice in the Nigerian context. It also attempts to trace the history and meaning of local government as the third tier of government. The paper equally examines the functions, structure and control of funds of local government councils within the existing legal framework in Nigeria. The last segment of the paper discusses the procedure of creating new local councils in the light of Constitutional provisions.

\section{The Concept Of Federalism In Nigeria}

Federalism is a purposive system of government that always has an end to attain. In a country like Nigeria or any other country where there is multiplicity of ethnic and tribal groups a unitary system of government is usually a source of bitterness and hostility on part of the national minority groups. ${ }^{1}$ Thus the significance of having federalism lies not only in the Constitutional or institutional structure but in the society itself because federalism serves as a device through which the federal qualities of the society are articulated and protected. ${ }^{2}$ The word federalism has its origin rooted in the latin term fidere which simple means to trust or

\footnotetext{
${ }^{1}$ Sagay, I., 'Nigeria: Federalism, the Constitution and Resource Control' A Paper Delivered at the Fourth Sensitization programme organized by the Ibori Vanguard at the Lagoon Restaurant, Lagos (2001)

2 Igbuzor, O., 'Constitutional Making and the Struggle for Resource Control in Nigeria' available at Igbuzor. @ cddnig.org (visited 31st October 2011)
} 
entrust some agreed ideals to a central entity of a given country. ${ }^{3}$ Technically, federalism is that form of government where the component units of the political organization participate in powers and functions sharing in a cooperative manner. ${ }^{4}$ So it is a phenomenon of intergovernmental cooperation that cuts across and a formal Constitutional division of power. ${ }^{5}$ It is a process of formation of a particular kind of political union with at least two autonomous but independent level of government. ${ }^{6}$ Federalism is equally described as an arrangement between governments, Constitutional device by which power and resources within a country are shared among two (or more) units of government. ${ }^{7}$ Nwabueze further described federalism in the following words:

an arrangement whereby power within a multi-national country are shared between a federal or central authority, and a number of regionalized governments in such a way that each unit, including this central authority, exists as a government separately and independently from the others, operating directly on persons and property with its territorial area, with a will of its own and its own apparatus for the conduct of affairs and with an authority in some matters exclusive of all others. In a federation, each government enjoys autonomy, a separate existence and independence of the control of any other government. Each government exists, not as an appendage of another government (e.g. the federal or central government) but as an autonomous entity in the sense of being able to exercise its own will on the conduct of its affairs free from direction by any government. ${ }^{8}$ Therefore, the various descriptions of federalism above depict the fact that federalism has been given different definitions by different experts depending on the angle from which the writer sights the concept. However, two things are common in the various definitions given- the cooperative function between two or more governments (units) and sharing of governmental powers between or among the federating units. It is obvious that federal system contemplates autonomous existence of the regional governments with certain interdependence among the levels of government without the federating units being necessarily subordinate to the central government.

Mowoe ${ }^{9}$ summed up that for a nation to achieve true federalism, there are some basic and fundamental essential structures that must be in existance. They are:

i. Voluntary submission of autonomy i.e. the various federating states or units must submit some of the

powers which formerly belong to them prior to adoption of federal system to the central government.

ii. Cooperation among the various levels of government.

iii. Powers of the sovereign state be shared among the federal, state and local government. ${ }^{10}$

However, there are other factors to be considered in addition to the above for a classical federalism. These include:

a. The need for a supreme written Constitution

b. A predetermined distribution of authority between federal and state government.

c. An amendment procedure which allows revision of the federal compact but by neither the federal government nor the state government acting alone.

d. A Supreme Court exercising powers of judicial review

e. Some measure of financial self-sufficiency. ${ }^{11}$

Looking at the Nigerian context, it is perhaps right to say Nigeria adopted federalism as the necessary system capable of accommodating and fitting the heterogeneous nature of Nigerian society which is characterized with over 35,000 square miles and diverse ethnic, nationalistic and linguistic groups. ${ }^{12}$ The 1999 Constitution ${ }^{13}$ as the supreme law of the land structured out the power sharing formula between the federal and state government, and it states out the functions of local government. The Constitution shares the legislative powers between the National Assembly and State House of assembly to the effect that legislative powers of the Federal Republic of Nigeria is vested in the National Assembly for the federation which shall consist of the Senate and House of Representatives ${ }^{14}$ while the legislative powers of a state is vested in the House of Assembly of the state. ${ }^{15}$ The powers of the National Assembly to make law for the federation is with respect to any matters that are contained in the exclusive legislative list of the Constitution ${ }^{16}$ and such matter is within the legislative competence of the National Assembly, and it may also legislate on matters contained in the concurrent

\footnotetext{
${ }^{3}$ Daud, K.A., 'An Appraisal of the Features of Nigerian Federalism' KSU-BJPL, Vol.2, 2009, P112

${ }^{4}$ Amuwo, K., et.al, (Eds) Federalism and political restructuring in Nigeria (Spectrum Books limited, Ibadan, 1998) P 341.

${ }^{5}$ Igbuzor, O., Op. cit, P3

${ }^{6}$ Jackson, R.J. and Stein, M.B., Issues in the Comparative Politics, Cited in Daud, K.A., Op. cit, P112

${ }^{7}$ Nwabueze, B., Constitutional democracy in Nigeria, Africa, Vol.1, (Spectrum Books Limited, Ibadan, 2003) P59

${ }^{8}$ Nwabueze, B., Constitutional Democracy in Africa, Vol.4, (Printmarks Ventures, Ibadan, 2004)

${ }^{9}$ Mowoe, K.M., Constitutional Law in Nigeria, Vol.1, (Malthouse Press Limited, Lagos, 2008) P47

${ }^{10}$ Ibid

${ }^{11}$ Igbuzor, O., Op. cit, P3

${ }^{12}$ Daud, K.A., OP. cit, P115

${ }^{13}$ The 1999 Constitution of the Federal Republic of Nigeria as amended (hereinafter referred to as "the Constitution")

${ }^{14}$ See Section 4(1) of the Constitution

${ }^{15}$ Section 4 (6) of the Constitution.

${ }^{16}$ The exclusive legislative list is contains in part I of the second schedule to the Constitution. The list is made up of 68 items, the item 68 gives an omnibus power to legislate on any matter incidental or supplementary to any matter mentioned elsewhere in the list.
} 
legislative list ${ }^{17}$ and any other matter with respect to which it is empowered to make laws in accordance with the provisions of the Constitution. ${ }^{18}$ While legislative powers of the state is restricted to any matter included in the concurrent legislative list and any other matter with respect to which it is empowered to make laws in accordance with the provisions of the Constitution. ${ }^{19}$

Likewise, the executive powers of the country are also shared between the federal and state governments. Section 5 of the Constitution provides that:

(1) Subject to the provisions of this Constitution, the executive powers of the Federation:

(a) shall be vested in the President and may subject as aforesaid and to the provisions of any law made by the National Assembly, be exercised by him either directly or through the Vice-President and Ministers of the Government of the Federation or officers in the public service of the Federation; and

(b) shall extend to the execution and maintenance of this Constitution, all laws made by the National Assembly and to all matters with respect to which the National Assembly has, for the time being, power to make laws.

Meanwhile, the executive powers of a state are vested in the governor of the state as provided in section 5 (2) thus:

Subject to the provisions of this Constitution, the executive powers of a State-

(a) shall be vested in the Governor of that State and may, subject as aforesaid and to the provisions of any Law made by a House of Assembly, be exercised by him either directly or through the Deputy Governor and Commissioners of the Government of that State or officers in the public service of the State; and

(b) shall extend to the execution and maintenance of this Constitution, all laws made by the House of Assembly of the State and to all matters with respect to which the House of Assembly has for the time being power to make laws.

From the foregoing section, the Constitution has made demarcation on exercise of executive powers between the federal and state governments so that the President implements and executes the laws made by the National Assembly while a governor implements and executes the laws made by the House of assembly of his state. However, a state governor is expected to be cautious in discharge of his executive powers within his state in order not to frustrate the exercise of executive powers of the federation. Section 5 (3) of the Constitution provides to the effect that-The executive powers vested in a State under subsection (2) of this section shall be so exercised as not to:-

(a) impede or prejudice the exercise of the executive powers of the Federation;

(b) endanger any asset or investment of the Government of the Federation in that State; or

(c) endanger the continuance of a Federal Government in Nigeria.

The entrenchment of subsection (3) in the Constitution further articulates principles of federalism- need for mutual cooperation between the levels of government and the existence of diverse autonomous entities under the central government. ${ }^{20}$

In a similar vein, the judicial powers have also been shared between the federal and state government. The judicial powers of the federation are to be exercised by the Courts established for the federation which include Supreme Court, Court of Appeal, Federal High Court, National Industrial Court and such other courts as may be authorized by law to exercise jurisdiction on matters with respect to which the National Assembly may make laws. ${ }^{21}$ At the state level, the judicial powers of the state shall be discharged by courts established for a state which include High Court of a state, Sharia Court of Appeal of a State, Customary Court of Appeal of a State and such other courts as may be authorized by law to exercise jurisdiction on matters with respect to which a House of Assembly may make law. ${ }^{22}$

\footnotetext{
${ }^{17}$ The concurrent legislative list is contains in part II of the second schedule to the Constitution. The list contains 30 items and it has categorically mentioned the matters that National Assembly can legislate on and those that state House of Assembly can legislate on. In an event of conflict between laws made by National Assembly and that of the State House of Assembly, the laws made by National Assembly shall prevail over that made by the state as provided in section 4 (5) of the Constitution.

${ }^{18}$ Section 4 (4) of the Constitution. An instance of matters that the National assembly may legislate on by virtue of this subsection is case of an Act for the implementation of treaty as provided for in section 12 of the Constitution where it states that: (1) No treaty between the Federation and any other country shall have the force of law to the extent to which any such treaty has been enacted into law by the National Assembly; (2) The National Assembly may make laws for the Federation or any part thereof with respect to matters not included in the Exclusive Legislative List for the purpose of implementing a treaty.

${ }^{19}$ Section 4 (7) of the Constitution. Though there is no list mention as residual legislative list in the Constitution however, some provisions of the Constitution have by implication contemplated for residual matters and it was held in the case of Edet Vs Chagoon (2008)2 NWLR Pt 1070 P85 at 92 that any item not being in the exclusive legislative list or in the concurrent legislative list and not matters incidental or supplementary to the execution of any of the powers in the exclusive legislative list or even the concurrent legislative list is residual matters. Being residual matters they are within the legislative competence of the House of Assembly of the state.

${ }^{20}$ See Mowoe, K.M., Op. cit, P47

${ }^{21}$ Section 6 of the Constitution

${ }^{22}$ Ibid, Section 6. It should be noted that, the Constitution treats the Federal Capital Territory as a state as provided in section 299 of the Constitution that-the provisions of this Constitution shall apply to the Federal Capital Territory, Abuja as if it were one of the States of the Federation; and accordingly -all the legislative powers, the executive powers and the judicial powers vested in the House of Assembly, the
} 
One other significant aspect of Nigerian federalism that is worth stating is the fiscal structure of Nigerian federalism. Fiscal federalism simply means the division of resources among the tiers of government in a federal system. It requires some measure of financial self-sufficiency that every federating unit should have the authority to develop their sources of revenue within their own territory. ${ }^{23}$ In Nigeria, state governments have the power to generate revenue within their states however, in terms of mines and mineral, the federal government has absolute control over all mineral resources either under or upon any land in Nigeria. ${ }^{24}$ The Constitution in this respect provides that- the entire property in and control of all minerals, mineral oils and natural gas in, under or upon any land in Nigeria or in, under or upon the territorial waters and the Exclusive Economic Zone of Nigeria shall vest in the Government of the Federation and shall be managed in such manner as may be prescribed by the National Assembly. ${ }^{25}$

In line with federal government control of all mineral resources, the Constitution mandated the federal government to keep a special account known as the federation account into which all revenues collected by the federal government shall be paid. ${ }^{26}$ Thus any amount standing to the credit of the Federation Account from proceed of revenue collected from minerals shall be distributed among the Federal, State Governments and the Local Government Councils in each State on such terms and in such manner as may be prescribed by the National Assembly. ${ }^{27}$

\section{Meaning And Evolution Of Local Government}

Concept of local government has no definite and precise accepted definition but the 1976 Local Government Reforms defined it as government at local level exercised through representative councils established by law to exercise power within defined areas with substantial control over local affairs as well as the staff and institutional and financial power to initiate and direct the provision of services, and to ensure that local initiative and response to local needs and conditions are maximized. ${ }^{28}$ While United Nations division of public administration defined local government as a political subdivision of a nation, or in a federal system, a state which is constituted by law and has substantial control of local affairs, including the power to impose taxes or exact labor for prescribed purposes. ${ }^{29}$ It was also defined as an administrative unit with a territory, administrative authority, power and relative autonomy. ${ }^{30}$ According to Orewa, local government is the lowest unit of administration to whose laws and regulations the communities who live in a defined geographical area with common social and political ties are subject. ${ }^{31}$

It can be inferred from the above definitions that local government is the first step in climbing the ladder of hierarchy of government in a federal system of government. The Federal Government is the sovereign national, the State Government, a quasi- sovereign and the Local Government, the infra-sovereign. It is infrasovereign, subordinate and subject to the control of the state government; yet it is a separate legal unit being a body corporate having a common seal, with powers to sue and to be sued, mainly providing obligatory municipal services. ${ }^{32}$ Therefore, local government is the government that is closest to the people, it takes control and care of local affairs of the indigenous community being the government at the grass root. And its operations are confined to a particular geographical territory with restricted initiative and control on matters affecting its locality alone.

Prior to the emergence of colonial administration, there were in existence various ethnic and tribal groups occupying the territory covered by the entity today called Nigeria. With the arrival of British government in Nigeria, indirect rule was adopted as the system of administration particularly in northern Nigeria where the

Governor of a State and in the courts of a State shall, respectively, vest in the National Assembly, the President of the Federation and in the courts which by virtue of the foregoing provisions are courts established for the Federal Capital Territory, Abuja. In line with this provision, the section provides for High Court of the Federal Capital Territory, Abuja, Sharia Court of Appeal of the Federal Capital Territory, Abuja and Customary Court of Appeal of the Federal Capital Territory, Abuja.

${ }^{23}$ Igbuzor, O., Op. cit, P3

${ }^{24}$ Ibid P12

${ }^{25}$ Section 44 (3) of the Constitution

${ }^{26}$ Section 162 (1) of the Constitution. The subsection provides thus -the Federation shall maintain a special account to be called "the Federation Account" into which shall be paid all revenues collected by the Government of the Federation, except the proceeds from the personal income tax of the personnel of the armed forces of the Federation, the Nigeria Police Force, the Ministry or department of government charged with responsibility for Foreign Affairs and the residents of the Federal Capital Territory, Abuja.

${ }^{27}$ Section 162 (3) of the Constitution. The Constitution further states that whatever sharing formula to be prescribed by the National Assembly shall take congnisance of principle of derivation which shall not be less than thirteen percent of the total revenue that accrued to federation account directly from any natural resources. See Section 162 (2) of the Constitution.

${ }^{28}$ Oruku, M., Local Government Administration and Revenue Generation (National Open University of Nigeria, Lagos, 2008) P3

${ }^{29}$ See Mowoe, K.M., Constitutional Law in Nigeria (Malthouse Press Limited, Lagos, 2008) P239

${ }^{30}$ Bello-Imam, I.B., Local Government in Nigeria-Evolving a Third Tier of Government (Heinemann Educational Books (Nig)PLC, Ibadan, 1996) P206 Cited in Afolayan A.F., 'An Appraisal of the Local government Administration in Nigeria' KSU-BJ PL, Vol.3, No.1, 2010, P67

${ }^{31}$ Orewa, G.O., Principles of Local Government cited in Mowoe K.M., Op. cit, P239

${ }^{32}$ Khalil, S., Shafie, G. and Adelabu, A., 'Modeling Local Government System in Nigeria' September 2011, Vol. 1, No.1, Kuwait Chapter of Arabian Journal of Business and Management Review 
existing traditional institutions support the indirect rule. ${ }^{33}$ In 1914, there was amalgamation of the southern and northern protectorates which led to the introduction of indirect rule in the southern province. The system was fairly assimilated in the western provinces but not easily in the eastern provinces where the traditional tribal structures were less suited to the system of indirect rule. ${ }^{34}$ Thus the traditional native authority rule that was in existence was converted into a system of local government. ${ }^{35}$ This process of transformation has been most rapid in eastern Nigeria where the practice of indirect rule was least firmly established, it has been most gradual in the northern Nigeria where the large and powerful emirates for long defied assimilation to the new order. ${ }^{36}$

From 1950s, local government system in Nigeria has experienced several reforms, during that period; the system was modernized and constituted on a representative basis. Colonial local administration revolved around traditional rulers, with the unit of local administration referred to as the native authority. ${ }^{37}$ These reforms continued without been necessarily significant until when strong agitation and clamor for representative democracy and establishment of a local government that is independent from the other levels of government which was informed by the way local government functioned at the mercy and control of regional or state governments. ${ }^{38}$ The agitation was to stop state governments from arbitrary interference with local government organs and to create a local government that would relate to the state government in the same way as the latter relates to the federal government. ${ }^{39}$

In 1976, the military government had carried out far reaching reforms in the local government system in Nigeria with a view to bringing about- uniform local government laws throughout the whole country, ${ }^{40}$ complete democratization of Local Government system, and abolition of provincial and divisional administrations. ${ }^{41}$ The 1976 reform represented a fundamental change in the development of local government in Nigeria. The reform was termed as revolutionary in the sense that it was the first time the country was given a common, single-tier structure of local government in place of the different structures of various states. ${ }^{42}$ The reform instituted statutory allocations of revenues from the federation account with the intention of giving local governments fixed proportions of both the federation account and each state's revenue. ${ }^{43}$ The other revolutionary face of the reform was that local governments were equipped with political, administrative and fiscal capacities. In other words, Local Government became a third tier of government with constitutional functions and responsibilities. ${ }^{44}$ Sequel to the local government reforms, local government was made the third tier of government in 1979 with Constitutional functions; however the financial position of local government councils during that period was not impressive. ${ }^{45}$ In 1989, the Constitution provided that there shall be allocated directly to local governments any amount standing to their credit as prescribed by the national assembly. ${ }^{46}$ It then followed by the 1999 Constitution which is the applicable legal regime in our current discussion.

\section{Functions Of Local Government Council}

Basically, in any system, local governments are essentially created to decongest the functions and burden of central government and to provide services that are local in character. Local governments serve as veritable and appropriate institutions for promoting democracy at the grass root. ${ }^{47}$ By virtue of this, they are well placed to mobilization of people politically through political education, political enlightenment and political

\footnotetext{
${ }^{33}$ Indirect Rule, in principle, was one of the nonviolent methods adopted by Britain in ruling her African colonies. It was the system of administration used by the colonial masters where by the European government stayed at the background and gave orders to the local Chiefs to enforce on the community. See Afolayan, A.F., Op.cit, P67.

${ }^{34}$ Oluyede, P.A.O., Peter Oluyede's Constitutional Law in Nigeria (Evan Brothers (Nigeria Publishers) Limited, Ibadan, 2001) P302

${ }^{35}$ Available record shows that the first local administration ordinance was the Native Administration Ordinance No. 4 of 1916 which was designed to evolve from Nigeria's old institutions the best suited form of rule based on the people's habits of thought, prestige and custom. See Adedokun, A.A., 'Local Government Tax Mobilization and Utilization in Nigeria: Problems and Prospects' P3

${ }^{36}$ Elias, T.O., Nigeria: The Development of its Laws and Constitution Cited in Oluyede, P.A.O., Op. cit, P302

${ }^{37}$ Adedokun, A.A., Op. cit, P4

${ }^{38}$ Afolayan, A.F., Op. cit, 67

${ }^{39}$ Mowoe, K.M., Op. cit, P243

${ }^{40}$ Oluyede, P.A.O., Op. cit, P316

${ }^{41}$ Essien, E.S., 'The Role of the Local Government in the Attainment of the United Nations Millennium Development Goals' Paper Delivered at a Conference Organized by the Local Government Resource Center of the Niger Delta Environment Relief Foundation, ElQueen Hotels, Rivers State, 2010

${ }^{42}$ Ukiwo, U., 'Creation of Local Government Areas and Ethnic Conflicts in Nigeria: the Case of Warri, Delta State' A Paper presented at the CRISE West Africa Workshop, Accra, Ghana, March 2006, P8

${ }^{43}$ Ekpo, A.H. and Ndebbio, J.E.U., 'Local Government Fiscal Operations in Nigeria' (March 1998) AERC Research Paper 73, African Economic Research Consortium, Nairobi

${ }^{44}$ Ukiwo, U., Op. cit, P8

${ }^{45}$ Oluyede, P.A.O., Op.cit, P322

${ }^{46}$ Ibid. See also Section 160 (4)(5)and (8) of the 1989 Constitution of Nigeria

${ }^{47}$ Oruku, M., Op. cit, P19. Local government is essentially created as a viable political and administrative organ for the transformation of all communities and for delivery of essential services to the citizens. The primary purpose of the local government and the basis for its existence is to create a mass development impetus to the grassroots transformation. See Lawal, T., and Oladunjoye, A., 'Local Government, Corruption and Democracy in Nigeria' (2010) Vol.12, No.5, Journal of Sustainable Development in Africa, P5
} 
actions. Thus Local Governments have become very useful instrument for the conduct of election at all levels of government. ${ }^{48}$ As such, the process of political recruitment is institutionalized and the institution can then help to train people for higher responsibilities. This is in line with the fact that political cultures and values are developed through government at the rural level. ${ }^{49}$

Local Governments are also established to provide certain basic essential socio-economic services. ${ }^{50}$ For this purpose they give priority to rural and agricultural development and encourage the use of land and labor thereby reducing unemployment of youths and the rush to urban centers. They also have the capability and opportunity to promote greater efficiency in the provision of social amenities. ${ }^{51}$ Therefore, local governments work in collaboration with the community groups and the citizenry in order to harness community energies and input into development. ${ }^{52}$ By and large, political participation at the local level and socio-economic role of Local Government are the two broad rational behind the establishment of Local Government as the third tier of government in federal state..$^{53}$

Notwithstanding the foregoing roles and purposes of Local Government mentioned above, the 1999 constitution have made detail provision with respect to statutory functions to be performed by Local government in Nigeria. The Constitution provides that the functions to be conferred by law upon local government councils shall include those set out in the fourth schedule to the Constitution. ${ }^{54}$ The fourth schedule states thus-

1. The main functions of a local government council are as follows:

(a) the consideration and the making of recommendations to a State commission on economic planning or any similar body on -

(i) the economic development of the State, particularly in so far as the areas of authority of the council and of the State are affected, and

(ii) proposals made by the said commission or body;

(b) collection of rates, radio and television licences;

(c) establishment and maintenance of cemeteries, burial grounds and homes for the

destitute or infirm;

(d) licensing of bicycles, trucks (other than mechanically propelled trucks), canoes,

wheel barrows and carts;

(e) establishment, maintenance and regulation of slaughter houses, slaughter slabs,

markets, motor parks and public conveniences;

(f) construction and maintenance of roads, streets, street lightings, drains and other public highways, parks, gardens, open spaces, or such public facilities as may be prescribed from time to time by the House of Assembly of a State;

(g) naming of roads and streets and numbering of houses;

(h) provision and maintenance of public conveniences, sewage and refuse disposal;

(i) registration of all births, deaths and marriages;

(j) assessment of privately owned houses or tenements for the purpose of levying such rates as may be prescribed by the House of Assembly of a State; and

(k) control and regulation of -

(i) out-door advertising and hoarding,

(ii) movement and keeping of pets of all description,

(iii) shops and kiosks,

(iv) restaurants, bakeries and other places for sale of food to the public,

(v) laundries, and

(vi) licensing, regulation and control of the sale of liquor.

\footnotetext{
${ }^{48}$ Ibid

${ }^{49}$ Afolayan, A.F., Op. cit, P67

${ }^{50}$ Mowoe, K.M., Op. cit, P242

${ }^{51}$ Afolayan, A.F., Op. cit, P67

${ }^{52}$ Oruku, M., Op. cit, P19

${ }^{53}$ There are different schools of thought with respect to reason and purpose of local governments. The democratic participation school believes that local government exists only for the purpose of bringing about democracy and to provide opportunities for political participation and socialization. While the utilitarian's believes that the essential function of local government is to provide services and it must be judged by its services. While other school believes that local government exist so as to contribute and help achieve national integration, evolution and consciousness. See Mowoe, K.M., Op.cit, Pp241-242.

${ }^{54}$ Section 7 (5) of the Constitution. By virtue of this subsection, local government must not exercise the functions set out in fourth schedule until such functions are conferred on it by law of House of Assembly of the state. However, when state conferred this functions to local government, it cannot exercise these function again with the local government. See the Case of Knight Frank and Rutley (Nig) Ltd Vs Attorney General of Kano State (1982) 2 NWLR Pt.6, P211. See also Afolayan, A.F., Op. cit, P71
} 
2. The functions of a local government council shall include participation of such council in the Government of a State as respects the following matters- the provision and maintenance of primary, adult and a. vocational education;

(b) the development of agriculture and natural resources, other than the exploitation of materials

(c) the provision and maintenance of health services; and

(d) such other functions as may be conferred on a local government council by the House of Assembly of the State. ${ }^{55}$

The above stated functions of local government reveal a dichotomization of the functions into two as contain under the schedule. According to Oluyade, the division is indeed significant as a local government council can discharge the duties listed under item 1 alone as exclusive for the local government while duties under item 2 are to be concurrently exercised by the local government and state government. ${ }^{56} \mathrm{He}$ further asserts that the functions to be conferred on local government in respect of item 1 must include power to make regulations while the functions listed in item 2 are clearly the responsibilities of the state or the federal government in some instances. ${ }^{57}$

\section{Structure And Control Of Funds Of Local Government Council}

The constitution contemplates a local government council that is constituted by democratically elected representatives of the people at the grass root as a separate independent tier of government. The constitution provides that- the system of local government by democratically elected local government councils under this Constitution is guaranteed and government of every state shall ensure their existence under a law which provides for the establishment, structure, composition, finance and functions of such councils. ${ }^{58}$

It further provides that- the person authorized by law to prescribe the area over which a local government council may exercise authority shall:

(a) Define such area as clearly as practicable; and

(b) Ensure, to the extent to which it may be reasonably justifiable, that in defining such area regard is paid to-

(i) The common interest of the community in the area,

(ii) Traditional association of the community, and

(iii) Administrative convenience. ${ }^{59}$

By virtue of this subsection, it is still within the province of state government to ensure the existence of the local government councils and provides for their structure, composition, finance and functions. ${ }^{60}$ Thus there exists a controversy as to the person authorized by law to prescribe the area of authority of local government council. One may ask whether it is the House of assembly that is empowered to regulate authority of local government councils in the state or the governor. The issue was clarified by court decision in case of Balogun and others Vs Attorney General of Lagos State ${ }^{61}$ where it was held that it was not within the contemplation of the makers of the Constitution that the state House of assembly will delegate to the governor the power to define the area of authority of a local government area without the House of Assembly setting out the standards which an area of authority of a local government must conform with. The legislation must not only validly pass a law for the establishment of a local government area, it must define such area. Similarly, when it comes to establishment of democratically elected local councils, neither the governor nor House of assembly of a state can suspend or dissolve elected councils members. ${ }^{62}$

In Jideonwu and others Vs Governor of Bendel State ${ }^{63}$ the High Court of Bendel State held that it is in conflict with section 7 of the constitution for a governor of a state to nominate and appoint members of management committee having dissolved or suspended democratically elected Local Government Councils without regard to the provisions or relevant local government law. In Abdulkadir Ojo Vs The Governor of Kogi

\footnotetext{
${ }^{55}$ These functions of local government are in peri materia with the functions of local government contained in section 27 and 28 of the Local Government (Basic Constitutional and Transitional Provisions) Act, The Laws of Federation of Nigeria 1990, CAP. 213.

${ }^{56}$ Oluyede, P.O.A., Op.cit, P321

${ }^{57}$ Ibid

${ }^{58}$ Section 7 (1) of the Constitution

${ }^{59}$ Section 7 (2) of the Constitution

${ }^{60}$ Yakubu, J.A., Constitutional Law in Nigeria (Demyaxs Law Books, Ibadan, 2003) P36

${ }^{61}$ (1981)1 NCLR 31

${ }^{62}$ See the case of Attorney General of Benue State Vs Umar (2008)1 NWLR Pt 1068 P311. It held that an elected person is not an employee of any body except the electorate the voted him into office. It is only the electorate who can fire him. In the instance case, councilors derived their mandate from the people who voted them in and are accountable to them. It is only the people who voted them into office that can or may abridge their tenure in office. See also Abubakar Vs Attorney General of the Federation (2007)3 NWLR Pt 1022 P601

${ }^{63}$ (1981)1 NCLR 31. However, the court decision in this case was based on section 7 of the 1979 Constitution which is in pari material with section 7 of the 1999 Constitution.
} 
State $^{64}$ where governor of Kogi state dissolved 21 local government councils pursuant to law made by the House of Assembly of the state (Kogi State Local Government (Amendment) (NO.3) Law, 2006). The court held that Kogi state House of Assembly has the power to make laws to regulate the affairs of the local government but such powers must be so exercised to be in conformity with the provision of the Constitution from whence the House of Assembly derives its powers and that the Kogi State Local Government (Amendment) (NO.3) Law, 2006 negates section 7 of the Constitution which guarantees democratically elected local council. ${ }^{65}$

Therefore, local council should be constituted by elective representatives of the people and it consists of Chairman of the council, Vice Chairman and Councilors. The Chairman serves as the chief executive and accounting officer of the council. Although he is not signatory to the council's account but he approves all payments to be made ${ }^{66}$ Being the chief executive he controls the affairs of the local government and allocates responsibility to other executives such as the Vice Chairman, Supervisors and Secretary to the local government. ${ }^{67}$ Meanwhile, the Vice Chairman who is elected together with the Chairman acts as Chairman in circumstances where the substantive Chairman is absent. He also discharges such responsibilities as may be assign to him by the chairman. ${ }^{68}$

Meanwhile, the councilors constitute the legislative arm of the local government and their primary responsibilities are law making and approval of local government budgets. The list of matters on which a Local Government Council is expressly empowered to enact bye-laws is contained in item 1of the fourth schedule of the constitution as the exclusive list. The concurrent list of matters on which both a Local Government Council and the State House of Assembly have powers to legislate on is contained in item 2 of the fourth schedule. ${ }^{69}$ Council decision is by simple majority and it is binding on the Chairman and he has no veto power to disregard decision of the Council. ${ }^{70}$ By and large, there is separation of the executive arm from the legislature arm of government. There is a separate legislative council and a separate executive council. The elected councilors constituted the legislature with its own speaker as the leader whose role was synonymous with speaker of the state house of assembly. Thus the relationship between the executive and legislative arm is synonymous with that of the State House of Assembly on the one hand the State Governor and his Commissioners on the other. A simple majority of the council in session is required to ratify the appointment of supervisors by the local government chairman. ${ }^{71}$

In terms of finance, a local government is expected to be independent of state government in a true federalism in such a way that state influence on the third tier could be avoided. However, in practice particularly within the Nigerian context, both federal and state governments are to make financial allocation from public revenue to local government. The Constitution provides that-Subject to the provisions of this Constitution the National Assembly shall make provisions for statutory allocation of public revenue to local government councils in the Federation; and the House of Assembly of a State shall make provisions for statutory allocation of public revenue to local government councils within the State. ${ }^{72}$ To clarify the process through which federal and state

\footnotetext{
${ }^{64}$ (2006)NNLR 472. In another similar case of Akan Vs Attorney General of Cross River State (1982)2 FNR 177 where the Governor of Cross River dissolved all elected local government councils pursuant to Dissolution of Local Government Councils Law No.4 of 1979 . The court held that the law was in conflict with and violated section 7 of the constitution. See also the case of Onusagba Vs Kogi State Governor (2002)NNLR 691

${ }^{65}$ Ekpe, JCA in Akpan Vs Umah (2002)7 NWLR Pt 767 P701 said-in as much as I do not doubt it is within the legislative powers of the state House of Assembly to make law to regulate a local government council in the state plagued with crisis or to make a law to prescribe for an event upon which happening a local government council is dissolved or the Chairman or Vice Chairman of a local government council is removed or vacates is made by the House of Assembly, which provides for nomination of membership of a council or appointment of an Administrator or Caretaker committee to replace a democratically elected council is inconsistent with the clear and unambiguous provisions of section 7 (1) of the 1999 Constitution which guarantees democratically elected local government councils and is therefore unconstitutional to the extent of the inconsistency.

${ }^{66}$ The Chairman is the Chief security officer of the local government and he is to maintain peace, order and good government in his local government.

${ }^{67}$ The secretary of council and the supervisory councilors are appointed by the chairman of council. Usually the secretary is a career civil servant and he serves as the head of administration in the local government. The secretary signs all cheques, contractual agreements and local purchase order, and he acts as the secretary to Executive Council meetings and General Council meetings. See Afolayan, A.F., Op. cit, Pp71-72. On the other hand, the supervisory councilors serve as the political heads of their respective departments and members of finance and general purpose Committee which in effect is the cabinet to the Local Government. They also give directives to executive heads of Local Government departments on general policy issues only, but not on the internal management of the department. It is also within the functions of supervisors to assist the Chairman to supervise the execution of Local Government projects within their respecti ve departments, and they carry out such other functions as Chairman or council may assign to them from time to time. See Essien, S., Op. cit, P7

${ }^{68}$ Afolayan, A.F., Op. cit, Pp71

${ }^{69}$ Essien, E.S., Op.cit, P8

${ }^{70}$ Afolayan, A.F., Op. cit, P72

${ }^{71}$ Oruku, M., Op. cit, P56

${ }^{72}$ Section 7 (6) of the Constitution. In the exercise of revenue-sharing or revenue allocation, each level of government is guaranteed a percentage from the central pool. In Nigeria, this pool is known as the Federation Account. For detail explanation see Akindele, S.T., et.al, 'Fiscal federalism and local Government finance in Nigeria' Available at http://unpan1.un.org/intradoc/groups/public/documents/CAFRAD/UNPAN008121.pdf (visited 20th October, 2011)
} 
governments may discharge the obligation imposed by section 7 of the Constitution, the Constitution provides in section 162 that:

(5) The amount standing to the credit of Local Government Councils in the Federation Account shall also be allocated to the State for the benefit of their Local Government Councils on such terms and in such manner as may be prescribed by the National Assembly.

(6) Each State shall maintain a special account to be called "State Joint Local Government Account" into which shall be paid all allocations to the Local Government Councils of the State from the Federation Account and from the Government of the State.

(7) Each State shall pay to Local Government Councils in its area of jurisdiction such proportion of its total revenue on such terms and in such manner as may be prescribed by the National Assembly.

(8) The amount standing to the credit of Local Government Councils of a State shall be distributed among the Local Government Councils of that State on such terms and in such manner as may be prescribed by the House of Assembly of the State.

From the foregoing subsections, the share of money to be distributed to local governments within a state is paid to the states into an account to be known as "State Joint Local Government Account". Upon receipt of such monies, the state government is to distribute to the various local governments the amount due for each local council. It was held in Attorney General of Lagos State Vs Attorney General of the Federation ${ }^{73}$ that states are not to keep the allocation received on behalf of their local government councils as their own money. Rather, such funds are required to be paid direct into the special account known as the State Joint Local Government Account and into which each state is also required in section 162 to add its own contribution to the local councils in the state on such terms and in such manner as may be prescribed by the House of Assembly of the state. However, Afolayan observed that, sadly state governments in Nigeria in flagrant disobedience of the provisions of the Constitution have failed, refused and neglected to open such joint account in favor of the local government or pay the correct amount to the local government concern. ${ }^{74}$ Perhaps, the reason for federal government paying monies into the state joint account is to make state government a trustee of the local councils and ensure that local governments are directly under the control and supervision of state government. ${ }^{75}$ However, state governments usually divert the entrusted monies meant for local government into states account and thereby making the statutory allocations made to local councils as major source of revenue for the state governments. Only a part thereof of the statutory allocation from the Federation Account is made available by most state governments to the local councils. ${ }^{76}$ It would have been safe if the federal government is making direct payment into the local councils' account but that would be inconsistent with the provisions of the Constitution as was decided in Attorney general of Ogun State Vs Attorney General of the Federation. ${ }^{77}$ The court held that section 3 of the Allocation of Revenue (Federation Account) Act, CAP.16, Laws of Federation of Nigeria 1990 as amended by Decree No.106 of 1992 in so far as it purported to regulate the allocation of any amount standing to the credit of the local governments in the Federation account directly to the local government Councils inconsistent with section 162 (5) of the Constitution of the Federal Republic of Nigeria 1999 and, it is void and unconstitutional. In the same vein, the National Assembly cannot validly make a law permitting direct allocation to the local government councils. It is obvious indeed that lack of direct funds from Federation Account to local councils hinders effective performance of local councils in discharging and delivering the necessary socio-economic services they suppose to render to their communities.

\section{Creation Of New Local Government}

The Constitution has provided for seven hundred and sixty eight local government areas in Nigeria and these are the only constitutionally recognized local governments that are entitled to grant from the Federation Account. ${ }^{78}$ However, the Constitution has given room for state governments to create more new local government areas following the relevant provisions of the Constitution. For the purpose of creating a new local government, Constitution provides that:

A bill for a Law of a House of Assembly for the purpose of creating a new local government area shall only be passed if -

\footnotetext{
73 (2004)18 NWLR Pt904 P1

74 Afolayan, A.F., Op. cit, P73. Ojealaro also observed that the local government laws of the states do not make any express provisions as regards the proportion or percentage of the finance of the states that ought to be paid into the joint local government account as envisaged by the 1999 Constitution. Ojealaro, B.P., 'The Legal Framework for the Financial Administration of Local Government Councils in Nigeria' (2003) Vol.1, No.2, Ambrose Ali University Law Journal, P29 also cited in Afolayan, A.F., Op. cit, P73

${ }^{75}$ Ibid

${ }^{76}$ Ibid

77 (2002)18 NWLR Pt 798 P232

${ }^{78}$ Section 3 (6)of the Constitution provides that There shall be 768 Local Government Areas in Nigeria as shown in the second column of Part I of the First Schedule to this Constitution and six area councils as shown in Part II of that Schedule.
} 
(a) a request supported by at least two-thirds majority of members (representing the area demanding the creation of the new local government area) in each of the following, namely -

(i) the House of Assembly in respect of the area, and

(ii) the local government councils in respect of the area,

is received by the House of Assembly;

(b) a proposal for the creation of the local government area is thereafter approved in a referendum by at least two-thirds majority of the people of the local government area where the demand for the proposed local government area originated;

(c) the result of the referendum is then approved by a simple majority of the members in each local government council in a majority of all the local government councils in the State; and

(d) the result of the referendum is approved by a resolution passed by two-thirds majority of members of the House of Assembly. ${ }^{79}$

By virtue of the above subsection, government of a state may create local government area after a bill to that effect has been passed by House of assembly of the state but the House of assembly should make adequate returns to each House of the National assembly to enable it make necessary amendments under section 3 and Part I and II of the first schedule to the Constitution. ${ }^{80}$ This position have received judicial flavor in the case of Attorney General of Lagos State Vs Attorney general of the Federation ${ }^{81}$ where Lagos state government have created 57 local government areas in the state without due return to the National Assembly. it was held that the 57 local government areas established by the Creation of New Local Government Areas Law No.5, 2002 are inchoate until the National Assembly passes the Act necessary under section 8 (5) of the Constitution of the Federal Republic of Nigeria 1999. Therefore, the new 57 local government councils in Lagos state are not entitled to receive fund from the Federation Account. In other words, the process of local government creation does not begin and end at the state level. The state may designate additional local governments it intends to create and pass it into law. Thereafter, the state should make adequate return to the National assembly for its approval before the newly created local governments be constitutionally recognised.

\section{Conclusion}

Federalism is a system where governmental powers are shared vertically among the three tiers of government-federal, state and local government. Local government as a third tier of government is meant to serve local affairs of the indigenous community being the government at the grass root. It can only serve people effectively when there are adequate resources to be channeled toward addressing the necessary socio-economic needs of the society. In Nigeria, a democratically elected local council is guaranteed and the major source of funds of the council is through statutory allocation from federal and state government. Experience has revealed that state governments are fond of withholding and depriving the local government their statutory allocation that is paid into the State Joint Local Government Account and thereby slowing the pace at which local government areas function and develop.

It is suggested that federal government should pay any amount standing to the credit of local governments in the Federation Account directly to local government councils in order to avoid the illegal and unnecessary deductions being made by the state governments. This can be achieved through Constitutional amendment by abolishing State Joint Local Government Account and mandating federal government to pay statutory allocations directly into local governments account. In the alternative, we suggest that the local government councils should take legal action against their state government in the event of illegal deductions from the local councils' coffers pending when the Constitution would be amendment.

\footnotetext{
${ }^{79}$ Section 8 (3) of the Constitution

${ }^{80}$ Mowoe, K.M., Op. cit, P247

${ }^{81}$ Op. cit
} 